\title{
Genetic Vulnerability of Modern Crop Cultivars: Causes, Mechanism and Remedies
}

\author{
Gemechu Keneni ${ }^{1,2, *}$, Endashaw Bekele ${ }^{2}$, Muhammad Imtiaz $^{3}$, Kifle Dagne ${ }^{2}$ \\ ${ }^{1}$ Holetta Agricultural Research Center, Addis Ababa, P. O. Box 2003, Ethiopia \\ ${ }^{2}$ Department of Biology, Addis Ababa University, Addis Ababa, P. O. Box 1176, Ethiopia \\ ${ }^{3}$ International Center for Agricultural Research in the Dry Areas (ICARDA), Aleppo, P. O. Box 5466, Syria
}

\begin{abstract}
Plant breeding is one way to confront the challenge of bridging the widening gap between the demand and supply of food. Despite the importance, however, plant breeding has its own negative side effects. The replacement of landraces with a few genetically uniform varieties depletes genetic diversity and provides ideal conditions for diseases and insect pests that called genetic vulnerability. The increasingly growing human population and the subsequently rising demands for more food, on the one hand, and the success of such efforts like the "Green Revolution" from adoption of genetically uniform varieties in many parts of the world, on the other, are the main driving force towards this narrow genetic base. It is, therefore, important to understand the phenomena and plan to minimize the risks from genetic vulnerability. Under marginal conditions where resource-poor farmers dominate, the current plant breeding strategies, variety release, registration and certification procedures leading to genetic uniformity should be reconsidered and some level of genetic diversity should deliberately be maintained in variety development programs. Genetic diversity can be introduced at different levels and in different ways which may include intra-varietal, inter-varietal, inter-parental and inter-specific diversities. Breeding for specific adaptation instead of wide adaptation, systematic spatial and temporal gene deployment, use of inter-specific varietal mixtures and integration of horizontal and vertical resistances have been suggested as solutions.
\end{abstract}

Keywords Genetic Vulnerability, Horizontal Resistance, Intra-Specific Diversity, Inter-Specific Diversity, Uniform Cultivars, Vertical Resistance

\section{Introduction}

Crop production plays a decisive role in world food supply to feed the alarmingly growing population (Borlaug, 2000). Nevertheless, the productivity of crop plants has usually been low as compared to the expectations. The important ways of bridging the gap between the actual and the expected productivity include genetic manipulation of the crops and the growing environment with the use of proper crop management and protection practices, which involve the use of high levels of agro-chemicals.

The inception of modern plant breeding in its advanced form may date back to the mid-1990's (Smolders, 2006). As a result of the efforts made hitherto, a number of improved varieties responsive to cultural and crop management practices have been generated and released to producers. The genetic advances in such varieties have resulted in tremendous crop productivity increase over the last many decades at least in potential areas. For instance, $50 \%$ of the cereals yield gain in the United States of America is attributed to genetic

* Corresponding author:

gemechukeneni@yahoo.com (Gemechu Keneni)

Published online at http://journal.sapub.org/plant

Copyright (C) 2012 Scientific \& Academic Publishing. All Rights Reserved improvement (Rubenstein et al., 2005). The father of the "Green Revolution" and a Nobel Peace Prize winner in 1970, the late Dr Norman Borlaug, repeatedly underlined and mathematically demonstrated that, had it not been for the scientific advancements during the last half of the century and a more fundamental level of achievements from the Green Revolution, life would have almost been impossible with the current level of population growth and the associated land scarcity (Borlaug, 2000; 2002).

Traditional crop production is generally characterized by genetic diversity within (and between) the crop species (Broerse and Visser, 1996; de Boef et al., 1996). Genetic diversity within a particular species, i.e. the level of differences among the individuals within a species for inherited attributes, can be continuously denuded by selective breeding, environmental adaptation and species extinction (Wagoner, 2004), but the concern here is denudation of diversity by selective breeding as an undesirable side effect of scientific advancement. As early as the 1840's, it had become clear that modern plant breeding, though indispensably important, is also not immune of some undesirable consequences (Rubenstein et al., 2005; Smolders, 2006). The replacement of local landraces with improved varieties of narrow genetic base has resulted in genetic erosion and rapid reduction in genetic diversity (Ford-Lioyd and Jackson, 1986; 
Rubenstein et al., 2005; Smolders, 2006). The subsequent result in genetic uniformity, in turn, led to what is known as genetic vulnerability (Marshall, 1977; Wolfe and Barrett, 1977; Agrios, 1978; Simmonds, 1979). Genetic vulnerability may be defined as the susceptibility of most of the cultivated varieties of a crop species to biotic (diseases and insect pests) and abiotic (adverse climatic changes) stresses due to similarities in their genotypes (Singh, 2002). Beyond doubt, relying on a narrow genetic base, at least as a partially essential prerequisite, will make the crops vulnerable to the stresses particularly to harmful diseases epidemics (Marshall, 1977; Wolfe and Barrett, 1977; Simmonds, 1979; de Boef et al., 1996; Sharma, 2001; Rubenstein et al., 2005; Smolders, 2006). Recent studies showed that the breeding of crop cultivars is still narrowing down the genetic base in many crops (Hiromoto and Vello, 1986; Lebot, 1992; Witcombe and Hash, 2000; Chung and Singh, 2008) even though some argue that plant breeding did not result in denudation of genetic diversity in some crops (Huang et al., 1996; Donini et al., 2000; Bowman et al., 2003; de Wouw et al., 2010).

Global agriculture is at a cross road as world population is expected to increase to 8.3 billion by 2025 and further expansion of the area cultivated is no more possible as cultivable land cannot be indefinitely increased (Borlaug, 2000). Farmers may attempt to improve their farming condition but it is now generally accepted that the farmer's own innovative capacity can lead only to a minor improvement over the current practices and more fundamental change can occur only if farmers are supported with formal science-based knowledge (Bunters et al., 1996). As the number of population is increasing, we cannot depend only on the traditional practices and future gains in food production have to come from intensification of the traditional practices, which involves the replacement of the landraces by improved varieties (Bunders et al., 1996; Borlaug, 2000). The replacement of local landraces with improved varieties of narrow genetic base, in turn, may lead to genetic vulnerability (Marshall, 1977; Wolfe and Barrett, 1977; Agrios, 1978; Simmonds, 1979; de Boef et al., 1996; Sharma, 2001; Rubenstein et al., 2005; Smolders, 2006). Is there any way out to compromise these contradictory phenomena for sustainable development in the future? We reviewed here in this paper the main causes and the mechanism of genetic vulnerability and suggested ways out of the associated problems.

\section{History and Consequences of Genetic Vulnerability}

The problem of pushing crop varieties to a state of extreme uniformity vis-à-vis the importance of maintaining some level of genetic diversity within a crop species against the occurrence of diseases, insect pests and climatic fluctuation was not realized when modern plant breeding began (de Boef et al., 1996). It was later proved from the analysis of the causal basis of some devastating effects like the Irish Potato
Famine in the 1840 s that relying on genetically uniform crop varieties with narrow genetic base leads to genetic vulnerability (Marshall, 1977; Wolfe and Barrett, 1977; Agrios, 1978; Simmonds, 1979; de Boef et al., 1996) as risks of that scale were virtually uncommon when hundreds of the traditional varieties with broad genetic base were still been grown (Simmonds, 1979).

Historically, there are many horrifying examples of the devastating effects of relying on such narrow genetic bases. Most of the losses are historically more associated with pathogens than they are with insect pests as the latter have less chance of mutation as compared to the former (Singh, 2002). The Irish Potato Famine resulted from the widespread of genetically uniform clone (of a single variety called Lumpers) and the outbreak of potato late blight (Phytophthora infestans) caused $80 \%$ yield reduction (Zadoks and Schein, 1979). As a result, millions of Irish people starved to death and other two million emigrated (Agrios, 1978; Russell, 1978; Nyvall, 1979; Zadoks and Schein, 1979). Similar drawbacks of uniform varieties were also evident from repeated devastations particularly in the USA where genetically uniform varieties have been continuously applied in production. The wheat stem rust (Puccinia graminis) which devastated wheat fields in 1917, the elimination of all oats derived from the variety Victoria by Victoria blight (Cochliobolus victoriae) in the mid 1940s and the southern corn blight (Helminthosporium maydis) resulted in crop loss estimated to $15 \%$ yield reduction in corn (Rubenstein et al., 2005) or in a loss of one billion USD (Agrios, 1978) in the early 1970 s could be mentioned as a few examples. A number of other examples are also available from Asian countries (Safeeulla, 1977) like the great Bengal famine in India in 1943 due a devastative disease (Cochliobolus miyabeanus) to rice (Asfaw, 2004). An excellent example of devastation of that scale by insect pests was encountered over a century ago in France when grapevine was totally wiped out by attacks on root stocks of Phylloxera vertifoliae until a resistant cultivar was introduced from the USA (Singh, 2002).

\section{Causes of Genetic Vulnerability}

\section{Narrow Genetic Base of Crop Varieties}

Narrow genetic base of the cultivated varieties is considered as the direct cause of genetic vulnerability (Marshall, 1977; Wolfe and Barrett, 1977; Agrios, 1978; Simmonds, 1979; de Boef et al., 1996; Rubenstein et al., 2005; Smolders, 2006). Normally, natural populations may suffer from natural calamities but they are still genetically more flexible to adapt themselves or to evolve with the calamities while commercial cultivars are genetically uniform that their population is inflexible enough to do so (Simmonds, 1979; de Boef et al., 1996). Natural population has either low genotype by environment interaction, enabling it to perform under both stressful and optimal conditions or, in a mixed population, genotype substitution may occur, such that 
plants which fail to produce under one set of conditions yield well under different conditions (de Boef et al., 1996). It could be assumed that, in natural population, the resistant individual to the existing race of the pathogen, whatever it is, produces more progeny than the susceptible individual because of the relative reproductive advantages. Each cycle of generation advancement to the next progeny may, therefore, result in further genetic improvement and adaptation. In a genetically uniform population, however, no individual can have a relative reproductive advantage over the other as they all are identical and no genetic change is expected as far as there is no mutational change in race of the pathogen, the environment and/or the host itself.

The production of hybrids by crossing inbred lines with a high degree of genetic uniformity has reduced the genetic diversity as compared to the open-pollinated varieties in crops like maize (Simmonds, 1979). Moreover, several high-yielding and diseases resistant varieties are continually developed by crossing and re-crossing with the already adapted standard varieties and these practices substantially reduce the genetic bases of the cultivars (Marshall, 1977).

Crop production characterized by genetic diversity is normally stable as compared to those characterized by genetic uniformity (Simmonds, 1979; de Boef et al., 1996) for a number of reasons. First, it would be difficult for the pathogen to evolve matching genes for large number of resistance genes existing in genetically heterogeneous genotypes as it does for homogeneous genotypes (Simmonds, 1979; Sharma, 2001). That is, the more the number of resistance genes in the host, the less likely the pathogen is to match all resistance genes at a time (Sharma, 2001). Secondly, it may be assumed that mixture cultivars may be characterized by more efficient use of growth resources (Willey, 1979) due to either spatial or temporal complementarities. Spatial and temporal complementarities may occur when the associated crops make efficient use of resources over space and time. Thirdly, the buffering effects of the components of a mixed cultivar reduce risks from stress (Amare, 1996; Dereje, 1999; Kemal, 2002) as all components of a mixed cultivar may not become susceptible to a given stress at a time (de Boef et al., 1996). Fourthly, when one component of a mixed cultivar becomes susceptible to a given stress, there may be a partial or full compensation by the other components because more resources would be available for compensatory growth by the latter. Fifthly, the reproductive advantage of the components of a mixed cultivar that resisted a given stress may result in more number of them in consecutive generations and each cycle of generation advancement to the next progeny may, therefore, result in further adaptation. Six, sometimes there may be mutual environmental modification conducive for the component crops as in faba bean and field pea mixed culture, an indigenous practice in Ethiopia, where faba bean provides a physical support to field pea thereby facilitate aeration that reduce foliar diseases while field pea, in turn, suppresses weeds for faba bean (Amare, 1996). The situation could be illustrated with simplified hypothetical scenarios demon- strating the comparative advantages of intra-specific or inter-specific varietal mixtures over their sole components. For three intra-specific or inter-specific varietal mixtures, for instance, a number of possible scenarios maybe expected in the presence or absence of a stress as shown in Figure 1.

\section{Widespread of Dominant Varieties}

Narrow genetic base of the cultivated varieties when it is alone may not always cause genetic vulnerability (Rubenstein et al., 2005). The problem is aggravated by the widespread use of one or a few genetically uniform varieties over a large hectarage (spatial dominance), which is considered the other prerequisite for the widespread of disease and insect pests as it provides ideal condition and creates vulnerability (Simmonds, 1979; Sharma, 2001; Rubenstein et al., 2005; Smolders, 2006). It is misleading that uniform varieties with narrow genetic base may succeed for the first year or two following release, become established on large hectarage and then may experience some serious loss such as unexpected disease epidemics. The continuous production of a single variety of the same crop year after year (use of monocultivar) will also facilitate diseases epidemics particularly when host plant resistance is defeated by the counteractive mutation of disease pests and pathogens (Marshall, 1977; Wolfe and Barrett, 1977; Agrios, 1978; Simmonds, 1979; de Boef et al., 1996; Rubenstein et al., 2005; Smolders, 2006).

\section{Failure of Vertical Resistance}

Varietal resistance may fail in a shorter period than it takes for the development of a new variety (Rubenstein et al., 2005). Failure of vertical resistance is considered as another causes of genetic vulnerability connected with a narrow genetic base. Vertical resistance is believed to be effected by a single or a few genes (monogenic or oligogenic) as opposed to horizontal resistance which is controlled by many genes (polygenic). It is, therefore, highly specific and liable to changes in races of pathogens (Marshall, 1977; Simmonds, 1979). It is easier for a pathogen or an insect pest to overcome vertical resistance as it is a matter of defeating a single or a few genes of the host through the counteractive generation of the corresponding virulent genes through mutation (Marshall, 1977; Wolfe and Barrett, 1977; Agrios, 1978; Simmonds, 1979; de Boef et al., 1996; Rubenstein et al., 2005; Smolders, 2006).

\section{Inadvertent Breeding for Susceptibility}

Inadvertent breeding for susceptibility followed by the exposure to infection of a variety not known in advance may also result in susceptibility to unforeseen diseases (Simmonds, 1979). One good case of inadvertent breeding for susceptibility was encountered in 1970s with the release of a new corn genotype (Texas male sterile, TMS) in the USA. Hybrids that contained this new characteristic had many desirable properties including resistance to the most common corn diseases. However, they were not resistant to a previously unimportant strain of a fungal disease, the southern corn leaf blight (Helminthosporium maydis). Ninety percent of the corn sown in the US in 1970 contained the TMS trait and also shared genetic susceptibility to this pathogen. The 
fungus encountered all this acreage of susceptible host and wiped out one fourth of the US corn crop in 1970, a loss of over one billion dollars in production! If the corn acreage hadn't been such a monoculture, the fungus wouldn't have been able to spread as rapidly, as it would have encountered barriers of genetically resistant cultivars.

\section{Mechanism of Genetic Vulnerability}

The mechanism of genetic vulnerability may be explained in terms of the so called "the gene-for-gene theory". This theory, postulated over five decades ago, states that "for every resistance gene present in the host, the pathogen has a gene for virulence" (Flor, 1971). Susceptible reaction would result only when the pathogen is able to match (matching interaction) all the resistance genes present in the host with the corresponding virulence genes and, if one or more of the resistance genes is unmatched (non-matching interaction), resistance reaction would result (Simmonds, 1979).

At molecular level, resistance is considered as the existence of specific interaction between the products of genes governing host resistance (proteins like chitinases and glucanases) and those conditioning pathogenecity (Higgins et al., 1998). The alleles for resistance in the host and those of avirulence in the pathogen produce specific compounds which recognize each other and interact to produce resistance response in the host. If products of the alleles from the two sources do not recognize each other and there is lack of interaction between the products of the genes for resistance and pathogencity susceptible reaction results in the host (Singh, 2002). Nevertheless, the available information is not sufficient for exhaustive explanation of the mechanism of genetic vulnerability as there are a number of deviations and specialties. For instance, vertical and horizontal resistances were found to be conditioned with the same set of genes depending on the difference in positions of the genes and their products in the metabolic pathway (Anderson, 1974).

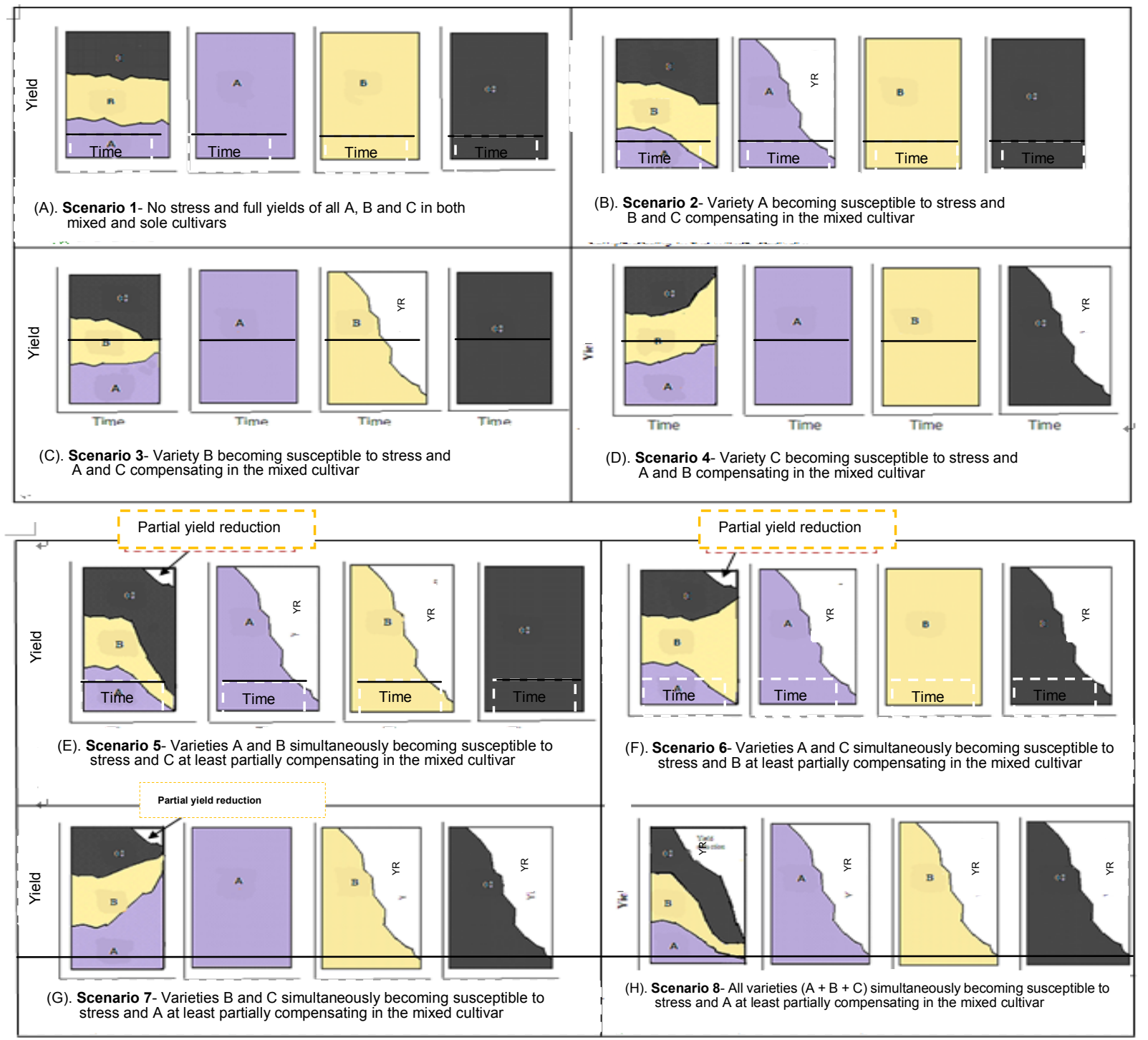

Figure 1. Hypothetical scenarios showing possibilities for comparative advantages of growing mixed $(\mathrm{A}+\mathrm{B}+\mathrm{C})$ or a multiline as compared to its sole components ( $\mathrm{A}, \mathrm{B}$ or $\mathrm{C}$ ) when different components possibly become susceptible to the stress under consideration $(\mathrm{YR}=$ yield reduction) 


\section{Genetic Vulnerability as an Issue of Potential Concern in Africa}

There are no full-fledged reports that sufficiently demonstrate the magnitude of genetic vulnerability encountered as a result of the use of modern crop cultivars in Africa. More concerns are rather raised against the replacement of landraces with improved varieties as a major cause of genetic erosion. A report by FAO (1996), for instance, warns losses of valuable crop germplasm in many countries of the world including Ethiopia in Africa, where native barley is stated suffering serious genetic erosion and durum wheat being lost due to the replacement of landraces with improved varieties.

It is obvious that improved cultivars of most of the crops are not yet sufficiently put under production (Borlaug, 2000; Rubenstein et al., 2005) and efforts like the Green Revolution did not replicate in parts of Africa partially because the agrochemical required along with the new varieties for soil fertility amendment and crop protection was unaffordable for the resource-poor farmers (Singh, 2000). Despite the least application of modern crop varieties, however, examples of genetic vulnerability might still be non-existent from the African experiences. One good example of genetic vulnerability due to use of narrow genetic base in Africa is the failure of hybrid maize as compared to traditional cultivars in Zimbabwe in response to dry years in the mid 1980's (Reijntjes et al., 1992). The production of rapeseed, a recent introduction to the state farms in Ethiopia, was totally abandoned due to outbreaks of blackleg (Leptosphaeria maculans) disease at epidemic level (Yitbarek, 1992). Failures of some crop varieties like in maize and wheat immediately after release due to their susceptibility to the major diseases have already been encountered in crops like maize and wheat in Ethiopia and, as a result, a number of them have shortly been put obsolete (Gemechu and Adugna, 2004).

There are sufficient technical and socio-economic reasons that force Africa to move towards technological breakthrough and modernization of agricultural production. Technically, plant breeding as a science seems to evolve towards genetic uniformity. The current technical innovations in breeding procedures like plant tissue and pollen cultures, for instance, aid the efficient development of genetically uniform cultivars (Snape, 1989; Zhang, 1989). Breeding, variety registration and seed certification procedures in the tropics are influenced by experiences from breeding in temperate areas (Banziger et al., 1998; Gemechu and Adugna, 2004) as there are less technical options to improve productivity by simultaneously encouraging the maintenance of genetic diversity in improved crop cultivars. Africa is also one of the continents benefiting from the centralized breeding efforts by the Consultative Group on International Agricultural Research (CGIAR), which mostly are developing uniform varieties with broad adaptation.

There are also high socio-economic ambitions to develop science-based agricultural production in Africa. First, agricultural development is not only a matter of food self- suf- ficiency and security but the sector is also considered by the governments as a leading economic sector for a rapid industrialization. Secondly, the number of population has continued to grow at an alarming rate and there is no reason that the increasing demand for food cannot force African countries to adopt and produce the best-performing cultivars over extensive geographic regions. Many countries inspire to mechanize crop production and this will definitely result in an ever-increasing replacement of old cultivars with newly developed uniform cultivars. Thirdly, varietal uniformity offers substantial economic advantages to growers, processors, packers and consumers in developed countries. It should not be overlooked that many African countries depend on the developed nations as a market place for their agricultural commodities (Smolders, 2006). Here, uniformity is economically valuable, as consumers pay premium price for uniform and high quality produce and hence farmers need to grow a few varieties that assure them high cash returns.

As plant breeders need to meet the national demands based on genetic uniformity, there is little doubt that the continued replacement of traditional landraces with a few genetically uniform varieties reduces the risk averting genetic diversity of the landraces, promote uniformity and leads to genetic vulnerability (de Boef et al., 1996). It is also simple to imagine that problems associated with genetic vulnerability, once happened in Africa at that scale, will have more severe consequences due to both biophysical and socio-economic reasons. First, production is highly marginal due to the fragile conditions where environmental degradation is maximal. Secondly, causes of genetic vulnerability like diseases and insect pests are more severe in tropical and subtropical regions in general and Africa in particular because of relatively more conducive conditions like higher temperature and relative humidity. Thirdly, the economic potentials of the most majority resource-poor farmers in Africa neither permits them to shoulder the risk nor to use purchased inputs like chemicals that confer crop protection.

\section{Do Modern Molecular Approaches Solve the Problem?}

Conventional breeding will continue to have a valuable role in providing resistance to biotic and abiotic stresses. Nevertheless, it appears that in some systems there will continue to be barriers to achieving resistance using this approach (Edwards and Singh, 2006). Molecular tools give us an opportunity to develop genotypes that carry resistance genes (Ranjekar et al., 2003) and these tools have been utilized in DNA fingerprinting for identification of cultivars, marker assisted selection and, to a limited level, for genetic modification in breeding for resistance (Ranjekar et al., 2003; Acosta-Gallegos et al., 2008). Problems associated with the need for long backcrossing cycles, gene pyramiding and the difficulties of crossing heterozygous clonally propagated 
crops with the conventional breeding method have already been resolved with the use of modern biotechnological tools (Higgins et al., 1998; Witcombe and Hash, 2000).

The identification of desired genes in related and unrelated species and efficiently incorporate these genes into the cultivars of interest (Poehlmand and Sleper, 1996) and a few resistance (R) and avirulence (avr) gene products have already been identified based on sequence comparisons (Higgins, et al., 1998). Not only identification of desired genes but also their transfer of these genes between related species is at least considered a modest possibility with the use of molecular tools (Humphreys, 2003). Practical examples for advanced-level use of biotechnology for breeding pest resistant varieties include the transfer of gene for insect resistance (cry gene) from a soil-borne bacteria (Bacillus thuringiensis) into the cultivated crops like cotton, maize, potato and soybean (Bowman et al., 2003). A case of successful transfer of a gene for tobacco mosaic virus resistance to tomato has also been reported (Higgins et al., 1998). There are a number of such examples but, despite the importance of biotechnological tools in facilitating genetic recombination and broadening genetic bases of newly developed cultivars, concerns about the problem of genetic uniformity and erosion of biodiversity may remain unresolved due to the use of techniques like cloning and tissue culture which produce almost perfectly identical copies.

\section{Remedial Measures against Genetic Vulnerability}

New plant breeding techniques in general lead towards high yield based on narrow genetic bases of various crops. It is not only the ambitions of research and development stakeholders but farmers' preference is also a driving force behind the replacement of landraces with genetically uniform varieties. As farming is getting competitive and competitive, no farmer can afford not to grow the best and highest yielding cultivars available to him (Rubenstein et al., 2005). The widespread use of one or a few genetically uniform varieties over large areas of land seems to be inevitable, which provides ideal conditions for diseases, insect pests and other natural disasters (Marshall, 1977; Wolfe and Barrett, 1977; Simmonds, 1979; de Boef et al., 1996). As mentioned above, the risk of such technological hazards, once happened, will be very severe particularly to resource-poor farmers in marginal areas where not only environmental fluctuations are great but also the economic potential of the farmers is unlikely to permit the use of purchased inputs like chemicals that confer crop protection. Genetic diversity declines with the reduction in total number of varieties being grown, increased concentration of area planted to a few favored varieties, or reduction in genetic distance between these varieties (Rubenstein et al., 2005). Therefore, the effect of genetic vulnerability should be minimized by application of proper breeding methods and by the systematic gene deployment.

\section{Breeding for Specific Adaptation}

There is no doubt that reasonable yields with fewer risks are preferable than high yields with high risks to the resource-poor farmers living under highly vulnerable condition and risk aversion, rather than yield maximization, must be the top priority. In such areas a process in which cultivars are adapted to fit the environment instead of the environment being altered to fit the cultivars is crucial for the development of sustainable agriculture (Coffman and Smith, 1991). In the marginal areas where problems of diseases, insects and environmental fluctuations and risks are great, specific adaptation to local circumstances, rather than broad adaptation, ensures varieties that are more closely situated to the physical environment, producer's needs and enhance genetic diversity in a given area (de Boef et al., 1996; Ceccarelli et al., 2004). The former assumption that breeding for potential areas would also result in better yields under marginal conditions was proved not to be valid for truly marginal environments (Ceccarelli, 1989) and, beyond doubt, we need separate breeding programs for the marginal and the potential areas. Specific adaptation to local circumstances, rather than broad adaptation, ensures varieties that are more closely situated to the producer's needs and enhance genetic diversity in a given area (de Boef et al., 1996). It is also obvious that the availability of alternate varieties enables to replace old varieties in case of any failure.

The habit of pushing varieties for release under marginal situations to a state of extreme uniformity by modern plant breeding has been criticized by several authors (Marshall, 1977; Wolfe and Barrett, 1977; Simmonds, 1979; de Boef et al., 1996). Under such situations, it is rather believed that uniformity is not biologically necessary or even desired but diversity can, at least sometimes, enhance performance and stability (Simmonds, 1979). Traits of interest to the resource-poor farmers in the marginal areas include yield stability, resistance to diseases, insects and abiotic calamities and low dependence on external inputs (de Boef et al., 1996). Farmers achieve these by deliberately creating genetic diversity at intra-varietal and/or interspecific levels (Weltzien and Fischbeck, 1990; Broerse and Visser, 1996; de Boef et al., 1996). Breeding activities to address this group of farmers should, therefore, build on farmers' practices to complement them and not to substitute their practices (Bunders et al., 1996). The physical environment and price ratios between external inputs and farm outputs do not allow the use of large quantities of purchased inputs, especially agrochemicals in large parts of the tropics and sub-tropics (de Boef et al., 1996).

\section{Systematic Gene Deployment}

The objective of crop production in the potential areas may be to increase production and productivity through the use of yield-increasing technologies like high-yielding varieties and agro-chemicals (de Boef et al., 1996). Genetic diversity can still be maintained through systematic gene deployment under potential conditions in different ways without hampering the need for mechanization to reduce the 
risk of genetic vulnerability. Some authors advise that we should increase the choice of germplasm available to farmers rather than to secure the adoption of a single or a few varieties over large areas (Simmonds, 1979; de Boef et al., 1996). The cultivation of closely situated fields into varieties with different resistance gene (spatial gene deployment) may diffuse the effects of diseases and insect pests (Marshall, 1977; Wolfe and Barrett, 1977; Simmonds, 1979; Rubenstein et al., 2005). Similarly, different varieties with different vertical resistance genes may be used in alternate years (temporal gene deployment) so that the evolution of the pathogen will be disturbed (Rubenstein et al., 2005). There are also a few evidence that when regions perpendicular to the direction of the wind are planted with alternative varieties with different genetic background (spatial gene deployment), each variety may act as a sieve for the pathotype virulent on the succeeding ones (Simmonds, 1979). However, the movement of pathogen in a definite pathway is not common (Sharma, 2001).

\section{Maintaining Broad Genetic Base in Varieties}

Several authors suggested that emphasis should be given to the maintenance of diversity in some planned fashion (Marshall, 1977; Wolfe and Barrett, 1977; Simmonds, 1979; de Boef et al., 1996). A wide range of breeding strategies may be employed to maintain variability within crop cultivars and minimize the consequent risks of genetic vulnerability. Variability may be maintained by stopping purification while there is still some residual heterogeneity left or by mixing late generation lines selected after homogeneity (Simmonds, 1979). Varieties developed through mass selection would also have considerable genetic variation because several similar looking plants which are variable for quantitative traits are selected and bulked (Singh, 2002). For instance, the development of synthetic varieties has been effective for increasing yield and stability in faba bean (Vicia faba L.) because heterozygosity is enhanced while at the same time the dangers of genetic vulnerability from varietal uniformity is reduced (Suso et al., 2005). A work in Kenya clearly showed that deliberately maintaining some level of variation in varieties turned out to be an important prerequisite of high grain yield in sorghum grown under drought stress (Haussmann et al., 2000).

The use of multiline varieties, i.e. mixtures of several similar pure lines having different genes for disease and insect pest resistance, in self-pollinated crops, may be expected to tolerate diseases and insect pests attacks better than their pure components (Marshal, 1977; Rajaram and Dubin, 1977; Trenbath, 1977; Simmonds, 1979; Zadoks and Schein, 1979; Welish, 1981). Mixtures with appropriate resistance genes could also help to reduce severities of multiple pathogens (Cox et al., 2004).

It should be born in mind during the constitution of multilines that plants morphologically look alike can be quite different genetically and the reverse may also be true (de Boef et al., 1996). Successful examples of multiline varieties were reported from different countries (Frey et al., 1977; Rajaram and Dubin, 1977; Simmonds, 1979; Frey, 1982) and the use of multiline varieties enabled pathogen-determined modification through withdrawal of susceptible components and replacement with new resistant lines (Wolfe and Barrett, 1977).

The dangers of genetic uniformity can also largely be avoided if plant breeders use different sources of genes (inter-parental diversity) in their breeding material and it would certainly be dangerous to rely too much on any one individual source of resistance (Russel, 1978). There are also speculations that crosses between parents with high inter-parental divergence would not only be more responsive to improvement since they are likely to produce higher heterosis and desirable genetic recombination and segregation in their progenies (Wallace and Yan, 1998; Chahal and Gosal, 2002) but also help to develop varieties with broad genetic base (Russel, 1978; Chandel and Joshi, 1983) that are not liable to genetic vulnerability (Chandel and Joshi, 1983). There is a possibility that, like many other traits including grain yield, heterosis maybe manifested through diseases and insect pest resistance (Singh, 2002).

The concept of maintaining some level of genetic diversity in varieties is getting little acceptance in many developing countries including that of Africa but attempts have already been started to breed in greater diversity in corn and wheat in the USA since the 1970s (Rubenstein et al., 2005). Recent assessments in cotton also showed a significant reduction in levels of genetic uniformity as a result of the decline in proportion of area planted to popular cultivars and buffering with the releases of alternative cultivars by increasing number of seed companies using different genetic backgrounds (Van Esbroeck et al., 1998; Bowman et al., 2003).

\section{Use of Inter-specific Varietal Mixtures}

Farmers, particularly in the tropics and sub-tropics, have been employing inter-specific varietal mixtures not only as a yield maximization and diversification but also as risk aversion strategies since time immemorial (Weltzien and Fischbeck, 1990; Broerse and Visser, 1996; de Boef et al., 1996). A number of later scientific investigations proved that the use of inter-specific diversity in crop cultivars reduced disease damage both on main and intercrops (Trenbath, 1977; Beets, 1982). Experiences from Ethiopia showed that mixing faba bean with field pea (Pisum sativum L.) (Amare, 1996; Dereje, 1999) and maize with haricot bean and sweet potato (Asefa and Tewabech, 1993; Asefa, 1997; Asefa, 1998) slowed down the rate of diseases development and resulted in higher yields of mixed crops as compared to the corresponding sole cultures.

Although it is generally believed that inter-specific diversity helps the components escape failure by reducing vulnerability to specific diseases, insect pests and climatic stresses (de Boef et al., 1996), it was observed in practice that increasing inter-specific diversity may enhance instead of reducing diseases and insect pest problems in that each species will bring with it additional pests (Marshall, 1977; Willey, 1979). It is, therefore, advisable to define a mutually beneficial set of crop species (Marshall, 1977). An experience with the performances of released varieties of faba bean 
and field pea varieties under sole and mixed cultures in Ethiopia showed that the incidence of chocolate spot (Botrytis fabae) was rather consistently higher in all varieties of faba bean under mixed cultures than the sole ones while, contrarily, the incidence of Ascochyta blight (Mycosphaerella pinodes) in field pea was consistently lower in all varieties of field pea under mixed cultures than the sole ones. As faba bean has inherently an erect stature with better air circulation when mono cropped, the inclusion of field pea as an intercrop could definitely create overcrowding beneath the canopy and then reduce free air circulation, create more humid condition as expected and exacerbate the level of chocolate spot incidence. On the other hand, field pea is a prostrate crop with all or part of the biomass lying on the ground when mono cropped and supported more or less in an erect position when mixed-cropped with faba bean. Therefore, it is logical to expect that mixed-cropping would rather create a relatively drier microenvironment unfavorable for the development of Ascochyta blight in field pea compared to mono cropping (Figure 2). The same study also showed that field pea was aggressive on faba bean maybe due to its climbing nature.

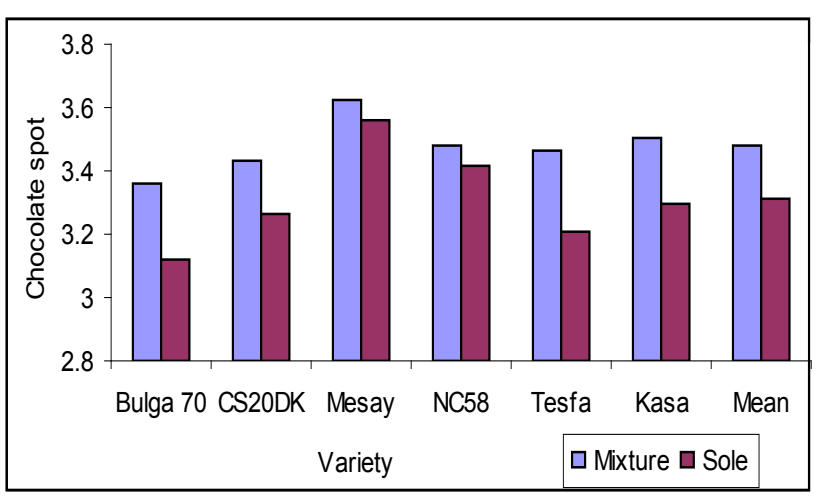

(A)Chocolate spot in faba bean

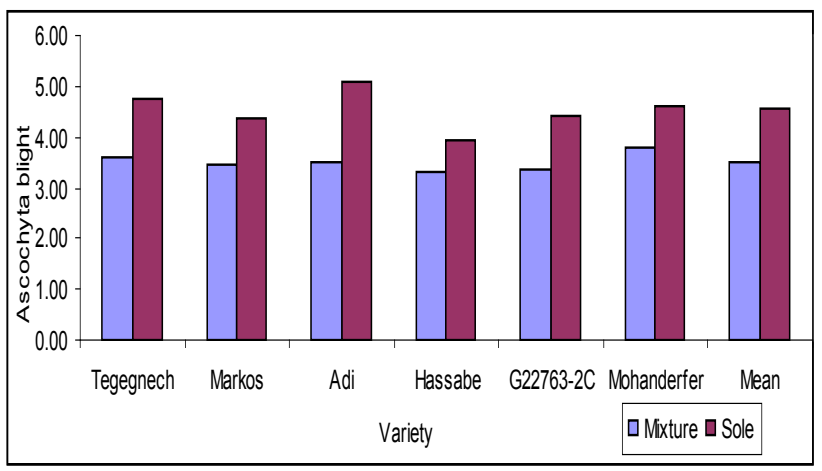

(B)Aschochyta blight in field pea

Figure 2. Effect of mixed-cropping of faba bean and field pea showing consistent aggravation of chocolate spot in faba bean (upper) and reduction of aschochyta blight (lower) in field pea with mixed cropping

\section{Integration of Horizontal and Vertical Resistances}

The comparative advantage of concentrating on horizontal (polygenic) resistance was realized earlier, as it is more durable and less liable to changes in races of pathogens as compared to vertical (monogenic or oligogenic) resistance (Marshall, 1977; Simmonds, 1979). Vertical resistance is known for its race specificity while horizontal resistance is known for non-specificity. In order to overcome the shortcomings of vertical resistance, more recently, the incorporation of vertical (monogenic) resistance with polygenic resistance (Higgins et al., 1998) and pyramiding (stacking) of genes for vertical resistance against a number of pathogenic races (combining several genes for vertical resistance into a single genotype through a "parallel" recombination strategy) were suggested to counter multiple races of diseases (Higgins et al., 1998; Sharma, 2001; Singh, 2002; Asfaw, 2004). Strengthening Local Breeding and Informal Seed System

In marginal areas where resource-poor farmers dominate and environments are highly variable, the enhancement of local breeding should be thought as one of the best strategies to overcome problems associated with genetic vulnerability of modern crop cultivars (Smolders, 2006). Farmers have been breeders since time immemorial and the key feature in local crop development is its maintenance of genetic diversity, both between and within species (de Boef et al., 1996). Local breeding involves the maintenance of local varieties (conservation through utilization), their enhancement (through selection and enrichment with exotic materials) and the seed system (production, selection, treatment, storage and exchange). For instance, existence of tremendous intra-cultivar diversity (for panicle size, shape, compactness and/or seed color) could easily be observed within known farmers' sorghum cultivars with the same designations but collected from different stopovers in northern Ethiopia (Figure 3). This indicates that the same cultivar might have intentionally or unintentionally been constituted from different genetic backgrounds. Farmers mostly use qualitative characters like morphological appearances like seed color to differentiate one intra-cultivar type from the others as "red Qatato" first from the left and "white Qatato" second from the left in Figure 3.

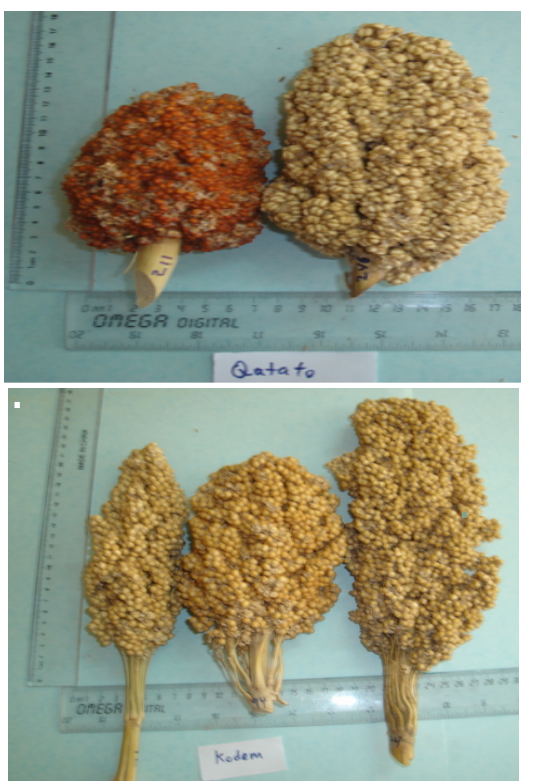

Figure 3. Partial view of intra-cultivar differences of two known farmers' cultivars, Qatato (upper) and Kodem (lower) showing phenotypic diversity in panicle size, shape, compactness and seed color 


\section{Summary and Conclusions}

Plant breeding is one way to confront the challenge of bridging the widening gap between the demand and supply of food. Despite the importance, however, plant breeding has its own negative side effects. The replacement of landraces with a few genetically uniform varieties depletes genetic diversity and provides ideal conditions for the pests, diseases and adverse climatic changes and creates genetic vulnerability. The increasingly growing human population and the subsequently rising demands for more food are the main driving force towards this narrow genetic base. It is, therefore, important to understand the phenomena and plan to minimize the dangers of genetic vulnerability.

We need neither to totally avoid genetic uniformity nor to oscillate between genetic uniformity and diversity. We should decide where to put what. Where mechanization is possible and economically feasible in the potential production areas, we should very systematically exploit the advantages of genetic uniformity resulting from the formal breeding and seed production programs. In the marginal areas where problems of diseases, insects and environmental fluctuations and, hence risks are great, we should reconsider the current breeding strategies leading to genetic uniformity. Since risk aversion strategies condition farmers' responses to new options, technologies and policies should confirm to and reinforce these strategies (Tilahun, 1995). Some level of genetic diversity should be deliberately maintained in variety development programs. Farmers should get encouraged to maintain, improve and enhance the locally adapted and diverse genetic materials with appropriate technical and policy supports.

\section{REFERENCES}

[1] Agrios, G.N. 1978. Plant pathology, 2nd edition, Academic Press, Inc., London.

[2] Amare Gizaw. 1996. Mixed cropping of faba bean and field fea in Ethiopia. PP 56-63 In Woldeyesus Senebo, Zerihun Tadele and Nigusse Alemayehu (eds.). Proceedings of the first and inaugural conference of Agronomy and Crop Physiology Society of Ethiopia (ACPSE), Addis Abeba.

[3] Anderson, R.G. 1974. Breeding for diseases resistance in wheat. Indian Journal of Genetics 34: 474-480.

[4] Asefa Teferi. 1997. Management of two major diseases of maize in Ethiopia. PP 913-920 In E Adipala,J.S. Tenywa and M.W. Ogenga-Latigo (eds.). African Crop Science Conference Proceedings. Pretoria, 13-17 Jan. 1997, Kampala, Uganda.

[5] Asefa Teferi. 1998. Effects of organic and mineral fertilizers on the intensity of turcicum leaf blight. PP 131-140 In Kidane Giorgis and Yohannes Degaga (eds.). Crop Management options to sustain food security. Proceedings of the 3rd Conference of the Agronomy and Crop Physiology Society of Ethiopia. 29-30 May 1997, Addis Abeba, Ethiopia.
[6] Asefa Teferi and Tewabech Tilahun. 1993. Review of maize diseases research in Ethiopia. PP 43-51 In Benti Tolessa and J.K.Ransom (eds.). Proceedings of the first national maize workshop of Ethiopia. 5-7 May 1992. IAR/CIMMYT, Addis Abeba.

[7] Banziger, M., G.O. Edmeades, D. Beck and M. Bellon. 1998. Breeding for drought and low $\mathrm{N}$ tolerance in maize. Regional workshop of breeders and agronomists of ASARECA member states, held at Arusha, Tanzania, September 1-14, 1998.

[8] Asfaw Adugna. 2004. Alternate approaches in deploying genes for diseases resistance in crop plants. Asian Journal of Plant Sciences 3(5): 618-623.

[9] Banziger, M., Edmeades G. O., Beck, D. and Bellon, M. 1998. Breeding for drought and low $\mathrm{N}$ tolerance in maize. Regional Workshop for Breeders and Agronomists of ASARECA Member States, held in Arusha, Tanzania, September 1-14, 1998.

[10] Beets, W.C. 1982. Multiple cropping and tropical farming system. Gower Publishing Company Limited. Gower House, U.K.

[11] Borlaug, N.E. 2000. The green revolution revisited and the road ahead. Special 30th anniversary lecture, the Norwegian Nobel Institute, Oslo.

[12] Borlaug, N.E. 2002. Agriculture and peace: The role of science and technology in the 21 st century. U Thant Distinguished Lecture Series, United Nations University, Tokyo.

[13] Bowman, D.T., May, O.L. and Creech, J.B. 2003. Genetic uniformity of the U.S. upland cotton since the introduction of transgenic cottons. Crop Science 43: 515-518

[14] Broerse, J.E.W. and B. Visser. 1996. Assessing the potential. PP 131-180. In J. Bunders, B. Haverkort and W. Hiemstra (eds). Biotechnology; building on farmers' knowledge. Macmillan, London and Basingstoke.

[15] Bunder, J., A. Loeber, J.E.W. Broers and B. Havertkort. 1996. An integrated approach to biotechnology development. PP 201-227 In J. Bunders, B. Haverkort and W. Hiemstra (eds). Biotechnology; building on farmers' knowledge. Macmillan, London and Basingstoke.

[16] Ceccarelli S., Grando, S., Baun, M. and Udupa, S.M. 2004. Breeding for drought resistance in a changing climate. pp. 167-190. In: Challenges and Strategies for Dryland Agriculture. Crop Science Society of America and American Society of Agronomy. CSSA Special Publication No. 32, USA.

[17] Ceccarelli, S. 1989. Wide adaptation: how wide? Euphytica 40:197-205.

[18] Ceccarelli, S. 1994. Specific adaptation and breeding for marginal conditions. Euphytica 77 (3):205-219.

[19] Chahal, G.S. and Gosal, S.S. 2002. Principles and Procedures of Plant Breeding:

[20] Biotechnological and Conventional Approaches. Narosa Publishing House, New Delhi.

[21] Chandel, K.P.S. and B.S. Joshi. 1983. Multivariate analysis in green-seeded pea. Indian Journal of Agricultural Sciences 53 (4): 198-200.

[22] Coffman, W.R. and M.E. Smith. 1991. Roles of public, in- 
dustry and international research center programs in developing germplasm for sustainable agriculture. In Sleper, D.A., Baker, T.C. Bramel-Cox, P.J. and Francis, C.A. (eds.). Plant breeding and sustainable agriculture: consideration for objectives and methods. Proceedings of a Symposium in Las Vegas, CSSA Publication No. 18: 1-9, Crop Science Society of America, Madison.

[23] Cox, C.M., K. A. Garrett, R. L. Bowden, A. K. Fritz, S. P. Dendy and W. F. Heer. 2004. Cultivar mixtures for the simultaneous management of multiple diseases: san spot and leaf rust of wheat. Phytopathology 94 (9): 961-969

[24] Chung, G. And R. J. Singh. 2008. Broadening the Genetic Base of Soybean: A Multidisciplinary Approach. Critical Reviews in Plant Sciences 27: 295-341.

[25] de Boef, W.S., T. Berg. and B. Haverkort. 1996. Crop genetic resources. PP 103-128 In J. Bunders, B. Haverkort and W. Hiemstra (eds). Biotechnology; building on farmers' knowledge. Macmillan, London and Basingstoke.

[26] Dereje Gorfu. 1999. Effects of mixed cropping of faba bean and field pea on disease development and yield. Pest Management Journal of Ethiopia 3: 61-67.

[27] de Wouw, V. M., T.V. Hintum, C. Kik, R.V. Treuren and B. Visser. 2010. Genetic diversity trends in twenty century crop cultivars. Theoretical and Applied Genetics. http://agro.biodiver.se/2010/01/breeders-not-so-bad-after-all/

[28] Donini, P., J.R. Law, R.M.D. Koebner, J.C. Reeves and R.J. Cooke. 2000. Temporal trends in the diversity of UK wheat. Theoretical and Applied Genetics 100:912-917FAO. 1996. http://web.icppgr.fao.org/info.html

[29] Flor, H.H. 1971. Current status of the gene-for-gene concept. Annual Review of Phytopathology 14: 275-296.

[30] Ford-Lioyd, B. and M. Jackson. 1986. Plant genetic resources: an introduction to their conservation and use. Edward Arnold, London.

[31] Frey, K.J. 1982. Multiple breeding. PP 43-71. In plant improvement and somatic cell genetics (I. K. Vasil, W.R. Scowcroft and K.J. Frey eds.). Academic Press, Inc., London.

[32] Frey, K.J., J.A. Browning. and M.D. Simons. 1977. Management systems for host genes to control diseases loss. PP 255-274 In P.R.Day (ed.). The genetic basis of epidemics in agriculture, the New York Academy of Sciences, New York, USA.

[33] Gemechu Keneni and Adugna Wakjira. 2004. Genetic Uniformity of Crop Cultivars: Challenges and Opportunities. Pages 1-9 In SEBIL. Vol. 10. Proceedings of the 10th Annual Conference of the Crop Science Society of Ethiopia. 19-21 June 2001, EARO, Addis Abeba.

[34] Gemechu Keneni and Mussa Jarso. 2003. Faba Bean Breeding for Waterlogged Vertisols of Ethiopia. Research Report No. 46. Ethiopian Agricultural Research Organization (EARO), Addis Ababa, Ethiopia.

[35] Haussmann, B.I.G., Obilana, A.B., Ayiecho, P.O., Blum, A., Schipprack, W. and Geiger, H.H. 2000. Yield and yield stability of four population types of grain sorghum in a semi-arid area of Kenya Crop Science 40: 319-329

[36] Higgins, V.J., Huogen, Lu, Ti Xing, Gelli, A. And Blumwald. 1998. The gene-for-gene concept and beyond: Interactions and signals. Canadian Journal of Plant Pathology 20: $150-157$.

[37] Hiromoto, D.M. and N.A. Vello. 1986. The genetic base of Brazilian soybean (Glycine max (L.) Merrill) cultivars. Brazil Journal of Genetics 2: 295-306.

[38] Huang, X., M. Wolf, M. W. Ganal, S. Orford, R. M.D. Koebner and M. S. Roder. 1996. Did modern plant breeding lead to genetic erosion in European winter wheat varieties? Crop Science 47: 343-349.

[39] Humphreys, M. O. 2003. Utilization of plant genetic resources in breeding for sustainability. Plant Genetic Resources 1(1): 11-18.

[40] Lebot, V. 1992. Genetic Vulnerability of Oceania's Traditional Crops. Experimental Agriculture 28:309-323

[41] Marshall, D.R. 1977. The advantages and hazards of genetic homogeneity. PP 1-20 In P.R.Day (ed.). The genetic basis of epidemics in agriculture, the New York Academy of Sciences, New York, USA.

[42] Nyvall, R.F. 1979. Field crops diseases handbook. AVI Publishing Company, Inc., Westport, Connecticut, USA.

[43] Poehlman, J.M. and Sleeper, D. A. 1996. Breeding Field Crops, 4th Edition, Iowa State University Press, USA.

[44] Rajaram, S and H.J. Dubin. 1977. Avoiding genetic vulnerabilityin semidwarf wheats. PP 243-254 In P.R.Day (ed.). The genetic basis of epidemics in agriculture, the New York Academy of Sciences, New York, USA.

[45] Reijntjes, C., Haverkort, B. and Waters-Bayer, A. 1992. Farming for the Future: An Introduction to Low- External-Input and Sustainable Agriculture. Macmillan, London.

[46] Rubenstein, D.K., Heisey, P., Shoemaker, R., Sullivan, J. And Frisvold, G. 2005. Crop genetic resources: An economic appraisal. United States Department of Agriculture (USDA). Economic Information Bulletin No. 2. (www.ers.usda.gov)

[47] Russell, G.E. 1978. Plant breeding for pest and diseases resistance, Butterworths, London.

[48] Safeeulla, K.M. 1977. Genetic vulnerability: the basis of recent epidemics in India. PP 72-85 In P.R.Day (ed.). The genetic basis of epidemics in agriculture, the New York Academy of Sciences, New York, USA.

[49] Sharma, J.R. 2001. Principles and practice of plant breeding. Tata McGraw-Hill Publishing Company Limited, New Delhi.

[50] Simmonds, N.W. 1979. Principles of crop improvement. Longman, London and New York

[51] Singh, B.D. 2002. Plant beeding: principles and methods. Kalyani Publishers, New Delhi-Ludhiana.

[52] Singh, R.B. 2000. Environmental consequences of agricultural development: a case study from the Green Revolution state of Haryana, India. Agricultural Ecosystem and Environment 82: 97-103.

[53] Smolders, H. 2006. Enhancing farmers' role in crop development: Framework information for participatory plant breeding in farmer field schools. Center for Genetic Resources, Wageningen University and Research Center, The Netherlands. 
[54] Snape, J.W. 1989. Doubled haploid breeding: theoretical basis and practical applications. PP 19-30 in review of advances in plant biotechnology, 1985-88 (A. Mujeeb-Kazi and L.A. Sitch eds.). 2nd International Symposium on Genetic Manipulation in Crops. Mexico, D.F., Mexico and Manila, Philippines: CIMMYT and IRRI.

[55] Suso, M.J., L. Harder, M.T. Moreno and F. Maalouf. 2005. New strategies for increasing heterozygosity in crops: Vicia faba mating system as a study case. Euphytica 143: 51-65

[56] Tilahun Mulatu. 1995. Indigenous risk management strategies of small farms in the Central Rift Valley of Ethiopia. PP 85-108 in food security, nutrition and poverty alleviation in Ethiopia: problems and prospects (Mulat Demeke, Wolday Amha, Simeon Ehui and Tesfaye Zegeye eds.). Proceedings of the Inaugural and First Annual Conference of the Agricultural Econmics Society of Ethiopia. 8-9 June 1995, Addis Ababa, Ethiopia.

[57] Trenbath, B.R. 1977. Interaction among diverse hosts and diverse parasites. PP 124-150 In P.R.Day (ed.). The genetic basis of epidemics in agriculture, the New York Academy of Sciences, New York, USA.

[58] Van Esbroeck, G., Bowman, D.T., Calhoun, D.S. and May, O.L. 1998. Changes in genetic diversity of cotton in the U.S. from 1970 to 1995 . Crop Science 38: 33-37.

[59] Wagoner, R. 2004. Genetic Uniformity.http://people.morehe adstate.edu/fs/r.wagoner/IET600/projects/project4.pdf

[60] Wallace, D.H. and Yan, W. 1998. Plant Breeding and WholeSystem Crop Physiology. University Press, Cambridge, UK.

[61] Welish, J.R. 1981. Fundamentals of plant genetics and breeding. John Wiley and Sons, New York, USA.

[62] Weltzien, E. and G. Fiscbeck. 1990. Performance and variability of local barley landraces in Near-Eastern environments. Plant Breeding 104: 58-67.

[63] Willey, R.W. 1979. Intercropping-its importance and research needs. Part I. Competition and yield advantage. Field Crops Abstract (32): 1-10.

[64] Witcombe, J.R. and C.T. Hash. 2000. Resistance gene deployment strategies in cereal hybrids using marker-assisted selection: Gene pyramiding, three-way hybrids, and synthetic parent populations. Euphytica 112: 175-186.

[65] Wolfe, M.S. and J.A. Barrett. 1977. Population genetics of powdery mildew epidemics. PP 151-163 In P.R.Day (ed.). The genetic basis of epidemics in agriculture, the New York Academy of Sciences, New York, USA.

[66] Yitbarek Semeane. 1992. Pathological research on noug, linseed, gomenzer and rapeseed in Ethiopia. pp. 151-161. Oilseeds Research and Development in Ethiopia. Proceeding of 1st National Oilseeds workshop. 3-5 December 1991, IAR, Addis Ababa, Ethiopia.

[67] Zadoks, J.C. and Schein, R.D. 1979. Epidemiology and plant disease management. Oxford University Press, New York.

[68] Zhang, Z.H. 1989. The practicability of anther culture breeding in rice. PP 31-42 in review of advances in plant biotechnology, 1985-88 (A. Mujeeb-Kazi and L.A. Sitch (eds.). 2nd International Symposium on Genetic Manipulation in Crops. Mexico, D.F., Mexico and Manila, Philippines: CIMMYT and IRRI. 